\title{
Total Quality Management in Indian Dairy Industry (A Comparative Study on Select Units in Dairy Industry)
}

\author{
G. Malathi*, Dr. R. Siva Ram Prasad** \\ *Asst.Professor, Maris Stella College, Vijayawada \\ **Professor, Acharya Nagarjuna University, Guntur, India
}

\begin{abstract}
Total Quality Management (TQM) plays an important role to improve the productivity and quality of the product in dairy industry. This paper seeks to make a comparative study on the TQM applications of cooperative and private dairy in Krishna District, Andhra Pradesh. A study was carried out to assess the Total Quality Management factors in each of the dairy. An extensive literature survey suggests that there are some important TQM factors like Quality Culture, Focus on Employee, Focus on Operations including Continuous Improvement, Focus on Customer and Strategic Competitive Management. Therefore for the purpose of the study the above mentioned five factors were taken to make a comparative analysis of the select units. The questionnaire was designed on five point Likert Scale to assess Total Quality Management. Coefficient of variation was used by the Researcher for the purpose of analysis.
\end{abstract}

Key Words: Total Quality Management, Total Quality Management factors, Coefficient of Variation.

\section{Introduction}

In the present competitive environment, survival of the organizations depends on their ability to continuously improve as per the expectations of the customers (Sun, 2000). Gitlow and Gitlow (1987) define quality as surpassing customer needs and expectations throughout the life of a product. Quality has been defined as conformance to requirements (Crosby, 1992), fitness for use (Juran, 1988a), meeting and/or exceeding customer's expectations (Parasuraman et.al., 1985), defect avoidance (Crosby, 1984) etc. Though there were wide variety of concepts surrounding the term "quality", all writers agree that quality is one of the important "critical success factors" to achieve competitiveness in organizations. Quality has expanded beyond the concept of "customer satisfaction with products and services" to the concept of "creation of worth for all stakeholders" (Karapetrovic and Willborn, 2002). In this context, overall business excellence is replacing the narrow objective of meeting customer specifications to improving the performance of the whole system.

Customer expectations for quality products and services have prompted organizations to adopt the principles of total quality management (TQM). Proponents of total quality management claim that TQM can be implemented in any organization and it can result into improved products and services, reduced costs, more satisfied customers and employees, and improved financial performance (Easton and Jarrel, 1998). Empirical studies show that TQM improves organizational performance (Powell, 1995). As a result of this correlation, numerous companies have adopted total quality management and there has been a flurry of interest in TQMrelated practices. In fact, TQM has been adopted in a wide variety of sectors including manufacturing, services, health care, governments and general administration. The success of TQM mainly depends on the achievement of internal as well as external customer satisfaction. Internal customer satisfaction is the prerequisite to achieve external customer satisfaction (Oakland, 1989). TQM therefore, can be simply defined as "managing the entire organization so that it excels on all the dimensions of products and services that are important to the customers" (Sharma, 1997). It can be stated that organization-wide participation in planning and implementing continuous improvement in quality (Shortell et al., 1995). Manufacturing organizations are more likely to achieve better performance in employee relation, customer satisfaction, operational performance and business excellence with TQM (Terziovski and Samson, 1999). In a large number of the Indian organizations, quality has been emerged as a key strategic issue due to the challenges posed by globalization and liberalization. Many organizations have taken the route of TQM to face these challenges. Many organizations have gone for ISO 9000 and QS 9000 certification to improve the quality of their products and services. These certifications and TQM implementation have coalesced into a major management movement. With the process of liberalization, India has initiated a comprehensive range of policy initiatives to provide a favorable environment for industrial investments and growth. 


\section{II.TQM in Indian Dairy Industry}

India is the world's largest milk producing country for past more than a decade. This is at a time when milk is being considered as complete food for every human being, Quality plays a vital role for Indian dairy industry from food safety point of view.

After 1992, due to World Trade Organization (WTO) \& General Agreement on Tariffs and Trade(GATT) agreement, world has become an open market for every product. Yet, to streamline quality parameters across the globe for every product, International organization for standardization (ISO) has derived various standards like ISO: 9001 for quality management, ISO-22000 for food safety management etc; which have direct impact with the Indian Dairy Industry. Again all these standards are revised from time to time considering rising demand of the customers and food safety. The pressure to sustain in business and to grow in open market across the world, Indian Diary Industry has accepted this challenge spontaneously and today, India is not only the highest milk producing country in the world but also a major exporter of various milk products to many countries. Today Gujarat Co-Operative Milk Marketing Federation Ltd. (GCMMF), very well know by Amul brand has achieved $15^{\text {th }}$ position in Dairy Industry of the world with respect to milk solids being handled by them. Yet, question comes in every one's mind, how this could happen and that too in very short span? For the same, the credit goes to various professional management tools being implemented in Indian Dairy Industry among which TQM has played a very vital role. TQM itself covers three major aspects viz. Total Quality Control (TQC), Total Employee Involvement (TEI) and Total Waste Elimination (TWE). Essence of these three combinations has helped to achieve quality Assurance in Indian Diary Industry. The word itself justifies about on assurance of quality of milk and milk products from consumer's perspective. At the same time stringent laws being introduced for human safety, Quality Assurance has become mandatory for every food processing industry and dairy industry is part of the same. Thus quality assurance is a key to the success of Indian diary industry for sustainable business growth. The same can be achieved and maintained through TQM practices.

\section{Review of Literature}

1. Mamta Patel et.al (2015), discussed the benefits and problems faced by Indian Milk Industry such as low quality, safety of milk and energy saving. The aim of this study is to apply PDCA (Plan- Do-Check-Act) approach to assess the causes that affect the productivity and quality of the dairy industry. After reviewing the literature they found some TQM factors like Top management commitment (Leadership), Supplier Quality Management, Customer Focus and Employee Participation to assess the quality in dairy industry. They identified that inefficient management and poor technology are the major problems for Indian Milk Industry and recommended that if all the TQM factors are balanced in a systematic way the concept of TQM and Deming's PDCA will provide competitive advantage to the Indian Milk Industry and it will result for higher productivity and profitability.

2. Dar Schniederjans and Marc Schniederjans (2015), seeks to examine the relationship between Social and Technical Quality management factors of TQM by collecting data from 58 respondents of manufacturing organizations at senior level. They identified various Social Quality Management factors like Quality Training, Cross-Functional Cooperation and Long Term Supply Relationships; Technical Factors like JustIn -Time management and Design for Manufacturability and Structural Factors like Organizational Size, Organizational Task and Managerial Ethical Evaluation to study the Quality Management and Innovation insights for Structural Contingency Framework. They concluded that Social Quality Management factors are positively associated with innovation and there is a reciprocal relationship between Social Quality Management and Technical Quality Management. In addition their research reveals that the positive relationship between quality management and innovation is moderated by the effects of organizational size, task and managerial ethics.

3. Neha Kalra and Anoop Pant (2013) examined the Critical Success Factors of Total Quality Management in the Indian Automotive Industry. Data was collected from the Manufacturers, Suppliers and Sub-contractors of Automobile organizations in National Capital Region of India. They identified 8 Critical Success Factors like Policy and Strategic Planning, Process Management and Control, Customer Focus and Satisfaction, Employee Focus, Information Management, Quality Leadership, Supplier Focus and Satisfaction and Organization Specific Business Result. Among these eight CSF's three CSF's like policy and strategic plan, quality leadership and customer focus and satisfaction are identified as the most important factors for automotive industry to generate higher revenue and profit.

4. Fuzi Abusa (2011) examined the impact of TQM implementation on Organizational Performance in developing country like Libya by selecting six different industry groups like: food, minerals, electronics and engineering, chemical, textile and furniture and cement and building materials. The extent of TQM application for selected industry groups was evaluated by using the TQM elements like Top Management Commitment, Customer Focus, Supplier Quality Management, People Management, Process Management and Continuous Improvement. Research questions were framed based on these six TQM elements. Among 
the six investigated TQM elements, Top Management Commitment is of critical importance in the success of TQM implementation and concluded that overall Competitive Position, Production Performance Improvement, Customer Focus, People Management, Process Management and Financial Improvement including Sales Growth and Profit Growth were achieved by Top Management Commitment only.

5. Faisal Talib et.al (2010), conducted a Pareto Analysis by identifying the list of Critical Success Factors for Service Industries. An examination of 39 TQM studies on CSF's resulted in listing of 60 CSF's by different researchers and practitioners of service industries. A Pareto Analysis was conducted on these 60 CSF's to sort out vital few CSF's for service industries according to their frequency of occurrences and 21 CSF's of TQM were extracted, among these 21 CSF's Top Management commitment was occupied first position followed by customer focus. These vital few CSF's were found to be key factors in almost all the research papers and are repeatedly used by the different researchers and concluded that Total Quality Managers and practitioners should focus on these 21 vital few CSF's to gain competitive advantage in the Service Sector.

6. Mujbil Al-Mrsumi(2009), examined the TQM practices adopted by five dairy processing units of Jordan. Investigation was conducted on the basis of five point Likert scale for TQM factors like Instilling Quality Culture, Focus on Employee, Focus on Operations including Continuous Improvement, Focus on Customers and Strategic Competitive Advantage. TQM factors for each company were considered as the Independent variables and the Quantity in tons of milk were considered as the dependent variable and the coefficient of correlation was used to measure the relationship between the TQM factor and quantity in tons of milk and identified that the most modern dairy processing units has achieved the highest score while the oldest and least modern scored the minimum and concluded that the correlation coefficient has a direct and consistent linear relationship between the quantity in tons of milk and TQM factors.

\section{STATEMENT OF THE PROBLEM:}

TQM refers to management methods used to enhance quality and productivity in business organizations especially in food industry and it is an important tool to improve the quality of the product in Dairy industry. In recent years, consumer concern and awareness about milk quality have increased. Sustaining customers and enhancing customer base has become the primary concern in dairy industry. This study aims to understand the TQM practices followed in the select units. In order to examine TQM in select units, the researcher identified five TQM factors to enhance quality in diary industry.

1. Instilling quality culture

2. Focus on employees

3. Focus of operations including continuous improvement

4. Focus on customers

5. Strategic competitive management

The above five factors were considered, through which the extent of the application of TQM in each company is measured. A questionnaire is designed based on the above mentioned quality factors.

\section{OBJECTIVES OF THE STUDY:}

1. To study the TQM practices adopted by select units in dairy industry.

2. To analyze and interpret the TQM factors that are followed in select units to enhance quality.

\section{FORMULATION OF HYPOTHESIS:}

Null hypothesis (H0): There is no significant difference in Total Quality Management factors of cooperative dairy and private dairy.

Alternative hypothesis (H1): There is a significant difference in Total Quality Management factors of cooperative dairy and private dairy.

\section{RESEARCH DESIGN:}

\section{SAMPLE AND SAMPLING TECHNIQUE:}

The study was conducted by selecting two milk processing units i.e. the cooperative dairy and private diary and 20 respondents from quality control department of each dairy were selected to examine the total quality management practices. In order to collect data from respondent's simple random sampling technique was used by the researcher.

\section{DATA COLLECTION:}

The data is collected through primary and secondary sources. Primary data is collected by using questionnaire consisting of statements on certain factors like:

1. Quality culture 
2. Focus on employee

3. Focus on operations including continuous improvement

4. Focus on customers

5. Strategic competitive management

Secondary data is collected through Journals, magazines and from the website of National Dairy Development Board.

\section{STATISTICAL TOOL:}

To analyze TQM factors coefficient of variation is used for the purpose of the study. Coefficient of variation (c.v) $=$ standard deviation $/$ mean $* 100$

Coefficient variation is a percentage variation in mean and standard deviation. In comparison, the coefficient of variation with smaller value is said to be more efficient and vice versa. Therefore the coefficient of variation with smaller percentile implies that they are adopting best TQM practices in dairy industry.

\section{SCOPE \& LIMITATIONS OF THE STUDY:}

1. The study focuses on five factors of TQM namely Instilling Quality culture, Focus on Employees, Focus on Operations Including Continuous Improvement, Focus on Customers and Strategic Competitive Management.

2. The study was confined to cooperative dairy \& private dairy in Krishna district of Andhra Pradesh.

3. The data was collected from the members of quality control department of select milk processing units.

4. The sample size used for the study is 20 from each dairy.

\section{Analysis and Discussion}

Analysis on Quality Factors of Cooperative Dairy and Private Dairy

\begin{tabular}{|l|l|l|l|l|l|l|}
\hline \multirow{2}{*}{ Quality factor } & \multicolumn{2}{|l|}{ Cooperative dairy } & \multicolumn{2}{l|}{ Private dairy } \\
\cline { 2 - 7 } & Mean & $\begin{array}{l}\text { Standard } \\
\text { deviation }\end{array}$ & $\begin{array}{l}\text { Coefficient of } \\
\text { variation }\end{array}$ & Mean & $\begin{array}{l}\text { Standard } \\
\text { deviation }\end{array}$ & $\begin{array}{l}\text { Coefficient } \\
\text { variation }\end{array}$ \\
\hline Instilling quality culture & 4.33 & 0.74 & 17.09 & 4 & 0.71 & 17.75 \\
\hline Focus on employees & 3.65 & 1.21 & 33.15 & 4.01 & 0.838 & 20.89 \\
\hline Focus on operations & 4.2 & 0.755 & 17.97 & 4.09 & 0.82 & 20.05 \\
\hline Focus on customers & 4.08 & 0.91 & 22.30 & 4.11 & 0.68 & 16.54 \\
\hline $\begin{array}{l}\text { Strategic competitive } \\
\text { management }\end{array}$ & 4.13 & 0.907 & 21.96 & 4.07 & 0.74 & 18.18 \\
\hline
\end{tabular}

Overall Quality Management application statistics

\begin{tabular}{|l|l|l|l|l|l|l|}
\hline \multirow{2}{*}{$\begin{array}{l}\text { Total quality } \\
\text { management factors }\end{array}$} & \multicolumn{4}{|l|}{ Cooperative dairy } & \multicolumn{4}{l|}{ Private dairy } \\
\cline { 2 - 8 } & Mean & $\begin{array}{l}\text { Standard } \\
\text { deviation }\end{array}$ & $\begin{array}{l}\text { Coefficient of } \\
\text { variation }\end{array}$ & Mean & $\begin{array}{l}\text { Standard } \\
\text { deviation }\end{array}$ & $\begin{array}{l}\text { Coefficient } \\
\text { variation }\end{array}$ \\
\cline { 2 - 8 } & 4.08 & 0.907 & 22.23 & 4.07 & 0.74 & 18.18 \\
\hline
\end{tabular}

\section{DISCUSSION:}

The mean, S.D and C.V were calculated for all the five factors of TQM. In the analysis of the first factor i.e Instilling Quality Culture the mean, S.D and C.V are 4.33, 0.74 and 17.09 respectively of cooperative dairy and that of private dairy are 4, 0.71 and 17.75 respectively which shows that both the units are almost successful in instilling quality culture. The second factor i.e. Focus on Employee, the mean, S.D and C.V are $3.65,1.21$ and 33.15 respectively of cooperative dairy and that of private dairy are 4.01, 0.838 and 20.89 respectively. The value shows that private dairy is more successful in focusing on employees than cooperative dairy. The third factor i.e. Focus on Operations, the mean, S.D and C.V are 4.2, 0.755 and 17.97 respectively of cooperative dairy and that of private dairy are 4.09, 0.82 and 20.05 respectively. The difference in coefficient of variation shows that cooperative dairy's focus on operations is quite better than private dairy. The fourth factor i.e. Focus on Customers, the mean, S.D and C.V are 4.08, 0.91 and 22.30 respectively of cooperative dairy and that of private dairy are 4.11, 0.68 and 16.54 respectively. The coefficient of variation is low for private dairy; this implies that their focus on customers is quite better than cooperative dairy. The fifth factor i.e. Strategic Competitive Management, the mean, S.D and C.V are 4.13, 0.907 and 21.96 respectively of cooperative dairy and that of private dairy are 4.07, 0.74 and 18.18 respectively. It is implied that private dairy is strategically more competitive than cooperative dairy. In overall TQM application statistics, the mean, S.D and C.V are 4.08, 0.907 and 22.23 respectively of cooperative dairy and that of private dairy are $4.07,0.74$ and 18.18 respectively. The difference in coefficient of variations shows that the implementation of TQM practices is very effective in private dairy than cooperative dairy. The above discussion shows that there is a significant difference in the TQM factors of cooperative dairy and private dairy. Therefore alternative hypothesis' is accepted. 


\section{Conclusion}

The analysis on TQM factors of cooperative dairy and private dairy showed that there is a very little difference in calculated values of instilling quality culture, focus on operations, focus on customers and strategic competitive management. There is much variation in the factor i.e. focus on employees. Therefore cooperative dairy has to take measures on various elements related to focus on employee like training and development, employee involvement and reward management to enhance the morale of the employees and to make them more committed towards their work.

\section{References}

[1]. Crosby, P.B., Quality without Tears, Mc-Graw Hill, New York, 1984

[2]. Crosby, P.B., completeness: Quality for $21^{\text {st }}$ century, Dutton Publisher, New York, 1992

[3]. Dara Schniederjans and Marc Schniederjans. Quality Management and Innovation: New Insights on a Structural Contingency Framework. International Journal of Quality Innovation, vol.1, no.2, 2015.

[4]. Easton, G.S. and Jarrel, S.L., The effect of total quality management on corporate performance: an empirical investigation, Journal of Business, Vol.71,1988

[5]. Faisal Talib, Zillur Rahman and M.N.Qureshi. Pareto Analysis of Total Quality Management Factors Critical to Success for Service Industries. International Journal of Quality Research, vol.4, 2010.

[6]. Fuzi Abusa. TQM Implementation and its Impact on Organizational Performance in Developing Countries: A Case Study in Libya. PhD Thesis. University of Wollongong.2011.

[7]. Gitlow, H., and Gitlow, S.J., the Deming guide to quality and competitive position, Englewood, Prentice-Hll, NJ, 1987.

[8]. Juran, J.M., Juran on Planning for Quality, Macmillan Publishers, London, 1988a.

[9]. Karapetrovic, S. and Willborn, W., Self-audit of process performance, International Journal of Quality and Reliability Management, 2002.

[10]. Mamta Patel and Raj kumar. TQM Implementation through PDCA Approach in Milk Industry- A Literature Survey. International Journal of Research in Technological Studies. Vol.2, issue.6, 2015.

[11]. Mujbil Al-Marsumi. Total Quality Management in the Top Rank of the Dairy Industry in Jordon. Jordan Journal of Mechanical and Industrial Engineering. Vol.3, no.1, 2009.

[12]. Neha Kalra Annop pant. Critical Success Factors of Total Quality Management in the Indian Automotive Industry. International Journal of Economy, Management and Social Sciences. Vol.2, no.8, 2013.

[13]. Oakland,J.S., Total Quality Management- The Route to Improving Performance, $2^{\text {nd }}$ Edition,Clays,St.Ives Plc., Great Britain, 1989.

[14]. Parasuraman, A., Zeithmal, V.A.and Berry, L.L., A Conceptual Model of Service Quality and its Implications for Future Research, Journal of Marketing, Vol.4, No.4, 1985

[15]. Powell, T.C., Total Quality Management as competitive advantage: a review and empirical study, Strategic Management Journal, Vol.13, No.2, 1995.

[16]. Sharma, S., TQM in Indian Engineering Industries, Business Publication Inc., New Delhi, India, 1997.

[17]. Shortell, S.M., Levin, D.Z., O'Brien, J.L. and Hughes, E.F.X., Assessing the evidence on CQI: Is the glass half empty or full empty? Hospital and Health Service Administration, Vol.40, 1995.

[18]. Terziovski, M.and Samson, D., The link between total quality management practice and organizational performance, International Journal of quality and reliable management, Vol.16, No.3, 1999.

[19]. Sun, H., Total Quality Management, ISO 9000 certification and performance improvement, International Journal of Quality and Reliability Management, Vol.17,No.2, 2000. 